\title{
The use of the kinesio taping in the extensor musculature of the knee after surgery of anterior cruciate ligament: case report
}

\author{
Utilização do kinesio taping na musculatura extensora do joelho após \\ cirurgia do ligamento cruzado anterior: estudo de caso
}

Flávia Maria Pinheiro Paulino1, Thiago Brasileiro de Vasconcelos², Érica da Rocha Pereira ${ }^{3}$, Maria do Socorro Quintino Farias', Vasco Pinheiro Diógenes Bastos ${ }^{1}$

\begin{abstract}
Introduction: The Kinesio Taping method (KT) was created by the Japanese chiropractor Kenso Kase in the 70s. He was trying to develop a tape which could help the normal function of the muscle tissue in order to give an external support without cause limitations to these tissues. Objectives: To evaluate the strength of extensor musculature of patients' knees in the post-operatory of the anterior cruciate ligament $(\mathrm{ACL})$ and compare the strength, power and resistance of the extensor musculature of the knee with and without the use of the tapes of the KT method. Method: The studying of the kind of the reported case, where it was applied the KT tape on the extensor musculature of a patient's knee who was undergone corrective surgery of ACL, it was used the Biodex SYSTME 3 PRO. Results: It was verified that in the first exam the left femoral quadriceps presented the deficit of strength, power and resistance related to the right one. In the third exam it was applied the KT tape and there was a decrease of the deficits of strength and power and an increase of the deficit of resistance. Conclusion: The use of the KT tape potentiates the gain of the strength and power of the weakened musculature and increase the values of the deficit of the muscle resistance and it can be a auxiliary resource in the physiotherapic treatment.
\end{abstract}

Keywords: Anterior cruciate ligament; Knee; Physiotherapy; Dynamometer.

\section{RESUMO}

Introdução: O método Kinesio Taping (KT) foi criado na década de 70 pelo quiroprata japonês Kenso Kase na tentativa de desenvolver uma bandagem que pudesse auxiliar na função normal dos tecidos, dando apoio ou suporte externo sem causar limitações na ação destes. Objetivo: Avaliar a função da musculatura extensora do joelho de pacientes no pós-operatório do ligamento cruzado anterior (LCA) e comparar a força, potência e resistência da dessa musculatura com e sem a utilização das fitas do método KT. Método: Estudo do tipo relato de caso, onde foi utilizado bandagem KT sobre a musculatura extensora do joelho em um paciente submetido à correção cirúrgica do LCA, utilizou-se o dinamômetro isocinético Biodex SYSTEM 3 PRO. Resultados: Verificou-se no primeiro exame que o quadríceps femoral esquerdo apresentou déficit de força, potência e resistência em relação ao direito. No terceiro exame foi aplicada a bandagem KT e houve uma diminuição dos déficits da força e potência e um aumento do déficit da resistência. Conclusão: $\mathrm{O}$ uso da bandagem KT aumenta a força e a potência da musculatura enfraquecida, porém, também aumenta o déficit da resistência do músculo.

Palavras-chave: Ligamento cruzado anterior; Joelho; Fisioterapia; Dinamômetro.

Corresponding author: Vasco Pinheiro Diógenes Bastos. Rua Monsenhor Catão, 1200, ap. 502, Meireles, Zip Code: 60175-000, Fortaleza (CE), Brazil. Phone: (85) 98730-0333. E-mail: vascodiogenes@yahoo.com.br

${ }^{1}$ Centro Universitário Estácio do Ceará (Estácio/FIC), Fortaleza (CE), Brazil.

Full list of author information is available at the end of the article.

Financial support: None.

Submission date 10 November 2015; Acceptance date 15 February 2016; Publication date 28 February 2016 


\section{INTRODUCTION}

In the 70s, the chiropractor Dr. Kenzo Kase created the Kinesio Taping Method (KTM) in an attempt to develop a bandage that could help in the normal function of tissues, supporting without causing limitations. It is a functional bandage that adheres to the skin, especially created to treat orthopedic injuries resulting from sports ${ }^{(1)}$, which has been used for therapeutic purposes in the rehabilitation of different types of patients in several areas, such as pediatric, neurological, rheumatological and esthetics. ${ }^{(2-4)}$

Kinesio tapes are elastic therapeutic tapes provided with $100 \%$ hypoallergenic acrylic, porous, heat sensitive, lengthwise extensibility is approximately $120-140 \%$ of its original length, thickness and weight similar to skin with marks that simulate fingerprints or existing veins in human skin and does not contain active ingredient. ${ }^{(1,5)}$ In support effect, it operates in postural re-education of the patient, stimulating muscle groups that inhibit other groups in order to provide a neuromuscular balance of injured segments. That makes it possible to improve contraction of a weakened or inhibited muscle, reduce muscle fatigue, decrease extreme and excessive retraction of the muscles and decrease the incidence of muscle cramps and injuries by applying the tapes skirting the muscle belly of the muscle that you want to stimulate or activate. ${ }^{(1,6)}$

Its use is indicated in practically all age groups and all musculoskeletal problems (muscle injury, capsular-ligament and tendon injuries, postural) and circulatory problems of the lower and lymph members. There are no contraindications; however, people who have dermal problems, allergies or irritations should be alert. ${ }^{(1)}$

The knee is one of the most complex joints and the largest of the body and is supported and stabilized by muscles and ligaments, often exposed to severe trauma. Patella, femur and tibia formed the articulations of knee joint. These structures constitute two different joints functionally related to each other, the patellofemoral and tibiofemoral joints. ${ }^{(7-9)}$

The Anterior Cruciate Ligament ( $A C L$ ) is an important ligament for containment of the knee joint complex. The rupture of this structure is the most common ligament injury of the knee, when only including complete ligament rupture, accounting for $50 \%$ of all ligament injuries. About $70 \%$ of $A C L$ injuries is due to maximum overloads during sports activities, particularly those involving deceleration movements, rotation and jumps. ${ }^{(10-13)}$ The $A C L$ injury occurrence is becoming more frequent, due both to automobile accidents as well as in sports; is predominant in males. Some authors believe that soccer is the main physical activity that leads to injury of this ligament. ${ }^{(14,15)}$

The aim of this study was to evaluate the function of knee extensor muscle in ACL postoperative patients and compare its strength, power and resistance variable with and without the use of KTM tapes.

\section{METHOD}

A case report study held at Kinesiology and BMTA ("Bases, Métodos e Técnicas de Avaliação" - Basis, Methods and Evaluation Techniques) laboratory in "Centro Universitário Estácio do Ceará (FIC)" and "Uniclinic Hospital" in August and September 2010. This study followed the ethical aspects that guide research with human beings and it was approved by Research Ethics Committee (REC) of the "Centro Universitário Estácio do Ceará" (Protocol 050/10).

The contraindications for performing isokinetic testing are painful affections with or without obvious clinical inflammation, insufficient time for tissue repair process, and decompensation of the cardiorespiratory system, such as uncontrolled hypertension, angina, and arrhythmia. The limitation of motion becomes a relative contraindication. ${ }^{(16)}$

The volunteer was asked to participate in the study by signing the Free, Prior and Informed Consent (FPIC). He did not present any exclusion criteria (skin diseases, infection or open wounds) and neither contraindication to perform isokinetic testing which allowed the inclusion of the same in the present study.

Data were collected through a form and evaluation performed on the Biodex SYSTEM 3 PRO isokinetic dynamometer. There were three assessments: the first and second were performed without the use of KTM tape in the 10th and 20th week of physical therapy, respectively, and the third evaluation was performed with the use of KTM tape two days after the second test.

The first two assessments were preceded by a warm up on a stationary bike for 10 minutes, and passive stretching of the lower limbs. The patient was stabilized at the Biodex by two-point belts, two laced crosswise in the trunk, while the other two were placed transversely with later examination.

The axis of the knee joint was aligned with the rotational axis of the equipment lever. The cushion that holds the dynamometer lever parallel to athlete's leg was positioned as distal as possible, immediately above the malleolus, without compromising the free ankle movement.

The isokinetic dynamometer was held in concentric mode for knee extensor and flexor muscle at three speeds $(60,180$ and $300 \%$ s), bilaterally. Was used verbal encouragement throughout the analysis and the volunteer was instructed to make maximum effort. The evaluation was performed first in the sound limb and then in the injured, fulfilling the same protocol for both.

The isokinetic evaluation, therefore, allows evaluating objectively and comparatively the muscular strength bilaterally, quantify the gains made by specific programs of physiotherapy and follow the evolution of patients.

The patient was instructed to not do physical activity that had as objective the strength gain of knee extensor and flexor muscles and to not make use of muscle relaxants for two days. The patient returned to the laboratory after these two days to 
repeat the isokinetic evaluation and brought proper clothing that would allow the application of the bandage over the rectus femoris muscle.

It was performed the circumference measurements of patient's thighs that showed a diameter difference of $1.5 \mathrm{~cm}$ for each circumference, revealing an atrophy of the operated limb. Then it was realized the goniometry of tibiofemoral joint, with values of $0-180^{\circ}$ for extension and $0-130^{\circ}$ for flexion bilaterally.

For applying the tape, the skin should be intact, clean and dry; excess body hair should be removed when they impede adhesion of the tape to the skin. It must be applied without any tension in bases and with muscle / tissue stretching. To have a better adherence of the tape in the skin is necessary to perform a friction on it during application. For its removal should be used mineral oil, milk of magnesia or water and pull it gently in the direction of the hair. ${ }^{(3,7,8,17)}$

The tapes can be cut into $\mathrm{Y}, \mathrm{I}, \mathrm{X}$, octopus, spider, containment, compressive and segmented shapes, according to the desired function. ${ }^{(1,3)}$ It was used the application of " $Y$ " shape because this is the type of application used in this study and have as main objective to promote support in chronic injuries.

In this study, skin cleansing was performed with alcohol and cotton; application of " $Y$ " shape KTM tape on the rectus femoris 30 minutes before heating. It was applied to the origin (anterior inferior iliac spine) for the insertion (tibial anterior tuberosity) involving the patella laterally. There was no need shaving the patient's thigh hair. The test was performed under the same technical conditions described above (Figure 1).

The bandage was beige, with a width of $5 \times 5 \mathrm{~cm}$, and applied from the source to the inclusion in the stretched

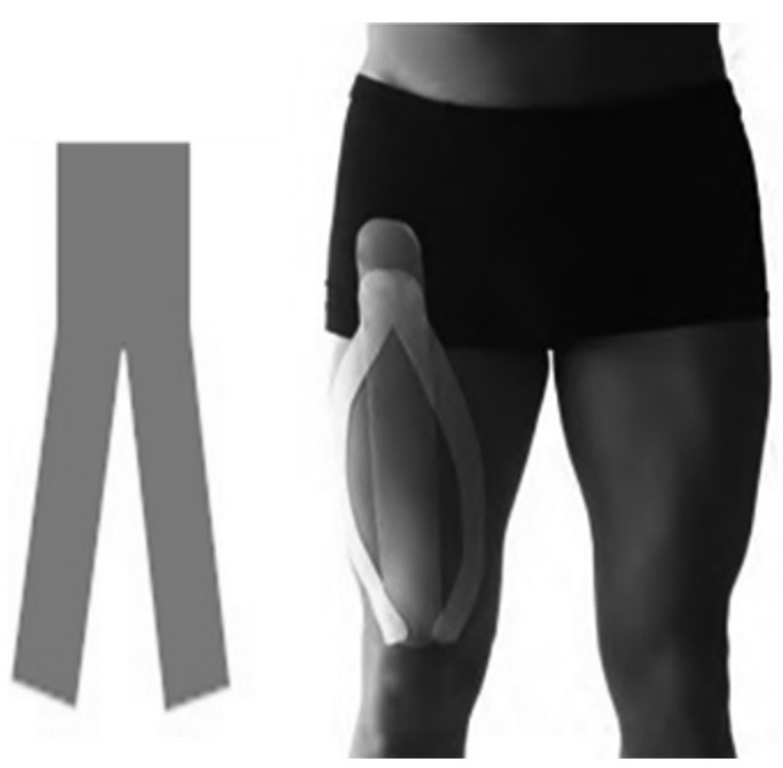

Figure 1. Demonstrative of applying kinesio taping with " $Y$ " shape tape. Source: Ares Kinesiology Tape www.arestape.com.br. muscle without making tension in the bandage bases supporting the muscle.

The extensor muscle was chosen for being potent, easy to access and facilitating the performance of isokinetic dynamometer.

Data were tabulated and presented in tables using Microsoft Office Excel 2007 software and adopting the significance level of $P<0.05$ (Student $t$ test).

\section{CASE REPORT}

Patient with drug-related problems (DRPs), 24 years-old, $68 \mathrm{~kg}$ (150 pounds), 1 meter and 78 centimeters (5 feet and 11 inches), male, single, student and professional indoor soccer player. He lives in Fortaleza, Ceara, Brazil.

In April 2010, during soccer practice, he was pushed by another player and sprained his right knee, which caused pain and local edema. The medical diagnosis based on specific tests indicated slight stretch of the medial ligament. The patient was referred for physical therapy. He returned to training 15 days and suffered a new twist in his right knee, but more intense.

In the second twist, he presented clinical picture of pain and swelling of greatest magnitude. He denies feeling or hearing a popping in the knee during twisting. The next day he restarted physical therapy on his own initiative, in which was required treatment in order to reduce local swelling and signs of inflammation, promote analgesia, proprioception and muscular strengthening. After three weeks of physical therapy, the patient had no pain and no swelling, normal range of motion and returns to training.

During walking or running, the volunteer reported misstep and blocking the tibiofemoral joint and sought medical help. Magnetic resonance imaging (MRI) confirmed the clinical diagnosis, which revealed a complete lesion of the anterior cruciate ligament $(A C L)$, partial lesion of the medial meniscus and inflammation of the medial collateral ligament (MCL), according to the report of the patient.

In May 18, 2010, the patient underwent a surgical procedure for $\mathrm{ACL}$ reconstruction with semitendinosus tendon graft and medial meniscus correction. In May 24, 2010, started physiotherapy treatment. In physical therapy initial assessment the patient walk with the aid of crutches and had painful condition, swelling, warmth and local erythema as well as restriction of tibiofemoral joint flexion and extension movement with goniometry of $50^{\circ}$ and $170^{\circ}$, respectively.

Chronological evolution of physical therapy:

- In the first three weeks of treatment means were used that aimed to tissue healing (tendon, joint capsule), analgesia and reduction of edema. It was used Transcutaneous Electrical Nerve Stimulation (TENS), ice and ultrasound of $1 \mathrm{MHz}$, as well as passive mobilization of patella. After removal of the sutures (stitches) started the cryokinetic and contrast techniques for range of motion gain and reduction of edema, respectively. 
- In the fourth week, it was held isometric exercises for fiber recruitment; exercises of the adjacent joints to maintain the physical conditioning from neighboring muscles to injured joint; Kabat method exercises performed on diagonal plan in different and progressive levels.

- In the fifth week began hydrotherapy with performance of weight discharge exercises on his knee. As well as manual therapy techniques, osteopathy, Mulligan and stretching to amplitude gain, since the patient had flexion of 100 degrees and full extension.

- In the sixth and seventh week, the rehabilitation focused on gait adaptation. Proprioceptive exercises and Kabat exercises for strengthening performed on the diagonal plan were intensified. Were added Exercises against elastic resistance (Thera-band) and stabilization exercises.

- In the eighth week, were performed exercises to strengthen extensor and flexor muscles, knee adductor and stabilizing the pelvis (glutes) with mecanotherapy equipment. Hydrotherapy exercises with races were intensified; and in the gait, mild hazing. It was used whirl, cryo and TENS at the beginning and end of the session to promote pain and fatigue relief due to the intensity of the exercises.

- In the tenth week, the patient underwent functional rehabilitation and physical conditioning activities (solo Pilate's ball and machine). It was performed the first isokinetic evaluation and began the isokinetic training in Biodex. It was intensified proprioceptive and aquatic exercises, as well as plyometric exercises.

- In the twelfth and thirteenth weeks, was performed the training for rehabilitation of the sport gesture with balls and races. In the following weeks, continued strengthening, conditioning and proprioceptive training, raising difficulty and intensity degree of exercises.

After the twentieth week of physical therapy, in the return to training, the patient underwent two isokinetic evaluations; the first was without the use of KTM tape and the second with the use of it. These tests enabled us to evaluate and compare the strength, power and endurance levels of knee extensor and flexor muscles.

In the first test, a measurement of the patient's thigh was made at 5, 10 and 15 centimeters above the upper edge of the patella, which had a diameter difference of 1,$4 ; 2,6$ and $3,5 \mathrm{~cm}$, respectively, between the left and the right leg, revealing a stunted member whose knee was performed surgery (Table 1 ).

Table 2 shows the values of the first and second tests performed on the tenth and twentieth week of therapy treatment, respectively. It displays the values deficit between the quadriceps muscle injured limb (right knee) in angular velocities $60^{\circ}, 180^{\circ}$ and $300^{\circ} / \mathrm{s}$.
There was an improvement of strength and power with physical therapy treatment developed, but gains were not observed in muscle group resistance tested.

In Table 3 are exposed data related to third isokinetic evaluation held two days after the application of KTM tape on the right quadriceps.

These data reveal a significant gain in strength and power rating due to the use of tapes in the test and a considerable deficit of resistance on the previous exam.

Figure 2 shows the deficits values produced by the quadriceps muscle (right side) in angular velocity of $60^{\circ}, 180^{\circ}$ and $300^{\circ} / \mathrm{sec}$ in all three dynamometer tests performed.

\section{DISCUSSION}

Studies involving the use of KTM are scarce and recent in the international literature. It is an innovative technique specially created to treat orthopedic injuries arising from the

Table 1. Distribution of data according to perimetry.

\begin{tabular}{cccc}
\hline $\begin{array}{c}\text { Measures above } \\
\text { patella }\end{array}$ & Left Thigh $(\mathrm{cm})$ & Right Thigh $(\mathrm{cm})$ & P \\
\hline $\mathbf{2}$ in & 39 & 37,6 & \\
$\mathbf{4}$ in & 46,5 & 44 & 0,63 \\
$\mathbf{6}$ in & 51,5 & 48 & \\
\hline
\end{tabular}

* Test T of two-tailed unpaired student (left thigh vs. right thigh).

Table 2. Distribution of data according to the initial evaluation.

\begin{tabular}{ccccc}
\hline $\begin{array}{c}\text { Muscle } \\
\text { Performance }\end{array}$ & $\begin{array}{c}\text { Right Rectus } \\
\text { Femoris - Tenth } \\
\text { Week }\end{array}$ & $\begin{array}{c}\text { Left Rectus Femoris - } \\
\text { Twentieth Week }\end{array}$ & Difference & P \\
\hline $\begin{array}{c}\text { Strength } \\
\text { (N-M) }\end{array}$ & 64,1 & 86,3 & 22,2 & \\
$\begin{array}{c}\text { Power } \\
\text { Rating (W) } \\
\text { Resistance } \\
\text { (\%) }\end{array}$ & 61,7 & 169,0 & 107,3 & 0,34 \\
\hline
\end{tabular}

${ }^{*} \mathrm{~N}-\mathrm{M}=$ newton-meter; $\mathrm{W}=$ watt e $\%=$ percentage. ${ }^{*}$ Test $\mathrm{T}$ of two-tailed unpaired student (left thigh vs. right thigh).

Table 3. Distribution of data according to the final evaluation.

\begin{tabular}{ccccc}
\hline $\begin{array}{c}\text { Muscle } \\
\text { Performance }\end{array}$ & $\begin{array}{c}\text { Right Rectus } \\
\text { Femoris - } \\
\text { Twentieth Week }\end{array}$ & $\begin{array}{c}\text { Right Rectus } \\
\text { Femoris with KTM }\end{array}$ & Difference & P \\
\hline $\begin{array}{c}\text { Strength } \\
\text { (N-M) }\end{array}$ & 86,3 & 134,7 & 48,4 & \\
$\begin{array}{c}\text { Power } \\
\text { Rating (W) } \\
\text { Resistance } \\
\text { (\%) }\end{array}$ & 169,0 & 183,2 & 14,2 & 0,36 \\
\hline
\end{tabular}

* $\mathrm{N}-\mathrm{M}=$ newton-meter; $\mathrm{W}=$ watt $\mathrm{e} \%=$ percentage. ${ }^{*}$ Test $\mathrm{T}$ of two-tailed unpaired student (left thigh vs. right thigh). 


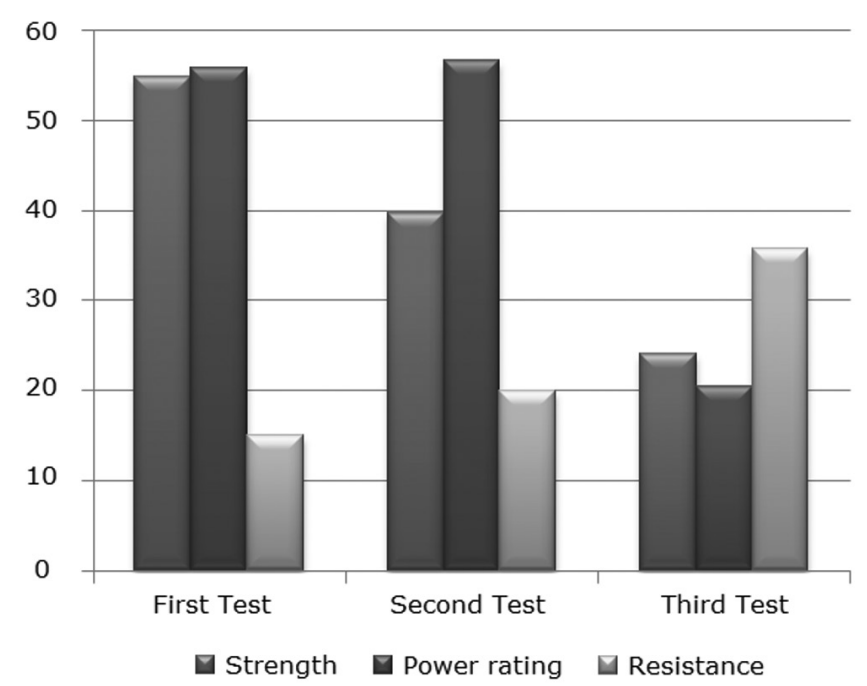

Figure 2. Distribution of data, according to quadriceps muscle deficits.

sport and used for therapeutic purposes in the rehabilitation of different types of patients.

In the available literature, we did not find studies that analyze the influence of the tape on the muscles in order to gain strength and our study is one of the pioneers to verify this possibility. However, there are some studies with the use of tapes ${ }^{(18-20)}$ for improved circulation, reduction of local edema and sensory stimulation providing stability and proprioception while performing movements, as well as improvement in muscle function with the increase of muscle fiber recruitment and correction of any joint misalignment. Moreover, it also causes pain relief, since it stimulates the sensory pathways in central nervous system increasing afferent feedback and reducing the direct pressure in the subcutaneous nociceptors.

The tape, when applied to the skin, may be able to adjust or correct joint misalignment, normalize the axis of motion of a joint and relieve the mechanical stresses exerted improving amplitude and quality of motion. ${ }^{(1)}$

According to Whiting and Zernicke ${ }^{(7)}$, the ACL injury occurs most often in response to a valgus load combined with external tibial rotation or in response to hyperextension with internal tibial rotation, corroborating the present study. May be associated with lesions of the collateral ligaments and the meniscus, especially in cases which it produces a trunk rotation relative to the lower ends. Studies suggest that this comorbidity may result from persistent kinematic gait disturbance after surgery and rehabilitation. ${ }^{(21)}$

Epidemiological studies in the United States reported that the incidence of $A C L$ injuries is $1 / 30$ individuals per year and $70 \%$ of these lesions are associated with competitive or recreational practice. ${ }^{(22)}$ The physiotherapy treatment for patients, who underwent reconstruction of the $A C L$ regardless the graft type, is extremely important to prevent loss of motion in the postoperative period and shorten the recovery time, mainly by reducing the signs of inflammation, analgesia, early mobilization, proprioception and range of motion gain, functional improvement, muscle strengthening and preparation for returning to sports activities. It should initiate in the immediate postoperative period and only discontinued in patient discharge. ${ }^{(23,24)}$

In this study, the initial isokinetic evaluations, without application of bandages, proved that the left knee extensor muscles showed a significant deficit in the angular speed of $60^{\circ}, 180^{\circ}$ and $300^{\circ} / \mathrm{sec}$. However, when comparing the first evaluation with the second, we conclude that there was a gain of strength and power rating, but there was an increase of resistance deficit in the quadriceps muscle group during the ten weeks of physiotherapeutic treatments that interspersed exams. When comparing the second test with the third (using KTM) it showed up a very significant gain of strength and power rating and an increase of resistance deficit in extensor muscle of the right knee in a short period of two days.

Studies prove the effectiveness of the use of tapes in the immediate post-operative total knee arthroplasty, by reducing the impact of damage caused in skeletal muscle, swelling, pain and promoting greater range of motion. The improvement of the venous return reduces edema, consequently, decreases the compression of nociceptive receptors decreasing pain and favoring increased range of motion. ${ }^{(25,26)}$

Matos $^{(1)}$ points out that the basic principle of therapy of functional elastic bandages to weakened muscles is to involve the affected muscle with tape giving support muscle. The ability to promote support happens during movement and motor activity. It is possible to improve muscular contraction of a weakened or inhibited muscle, reduce extreme and excessive retraction of muscles and reduce the possibility of injuries and muscular cramps.

The results between the second and third test are positive for an improvement of strength and power rating, although, without reducing the deficit resistance. However, the study was limited to the analysis of a single case, being necessary to carry out more comprehensive studies and presentation of results from long periods of treatment with KTM, among other relevant approaches.

\section{CONCLUSION}

The use of KTM tapes on weakened muscles potentiated the strength and power gains; however, it showed a significant deficit of resistance. Nevertheless, the use of KTM tapes can be a potential resource for therapy during postoperative rehabilitation of anterior cruciate ligament reconstruction.

\section{AUTHOR'S CONTRIBUTION}

FMPP participated in the elaboration, data collection and writing of the article; TBV and MSQF participated in data analysis, writing and editing; ERP participated in preparing and writing; VPDB participated in orientation, writing and final review of the article. 


\section{COMPETING INTERESTS}

The author(s) declare that they have no competing interests.

\section{AUTHOR DETAILS}

${ }^{2}$ Universidade Federal do Ceará (UFC), Fortaleza (CE), Brazil. 3. Universidade de Fortaleza (UNIFOR), Fortaleza (CE), Brazil.

\section{REFERENCES}

1. Matos N. Kinesio Taping: conceitos e aplicações no mundo do desporto. Revista Training. 2002, p. 10-12.

2. Ribeiro MO, Rahal RO, Kokanj AS, Bitar DP. O uso da bandagem elástica Kinesio no controle da sialorréia em crianças com paralisia cerebral. Acta Fisiátr. 2009;16(4):168-172.

3. Figueiredo H, Ulysséa M. Kinesio Taping. COFEERJ - Comitê de fisioterapia Esportiva do Estado do Rio de Janeiro. [10 maio 2010]. Disponível em: http://www.cofeerj.com.br/pdf/aulas/Kinesio_Taping.pdf.

4. Silva AC, Ferreira AAS. Achados anatômicos do complexo articular lateral do tornozelo: implicações nas dores crônicas e considerações para as mobilizações da fíbula. Revista terapeuta manual 2010;8(40):491-496.

5. Fu Tc, Wong Am, Pei Yc, Wu Kp, Chou Sw, Lin Yc. Effect of kinesio taping on muscle strength in athletes-A pilot study. J Sci Sport 2008;11(2):198-201.

6. Kaya E, Zinnuroglu M, Tugcu I. Kinesio taping compared to physical therapy modalities for the treatment of shoulder impingement syndrome. Clin Rheumatol 2011;30(2):201-207.

7. Whiting WC, Zernicke RF. Biomecânica da lesão musculoesquelética. Rio de Janeiro: Guanabara Koogan; 2001.

8. Santos JC, Giorgetti MJS, Torello EM, Meneghetti CHZ, Ordenes IEU. A influência da kinesio taping no tratamento da subluxação de ombro no acidente vascular cerebral, relato de caso. Revista neurociência, v. 18, n. 3, p. 335-340, 2010.

9. Hoppenfeld S. Propedêutica ortopédica: coluna e extremidades. 1 ed. Rio de Janeiro: Atheneu; 2002.

10. Hebert S, Barros-Filho TEP, Xavier R, Pardini-Junior AG. et al. Ortopedia e traumatologia: princípios e prática. 4 ed. Artmed: Porto Alegre; 2008.

11. Faustino CAC. Reconstrução do LCA com o uso de tendões dos músculos flexores medias do joelho e fixação femoral com o sistema de Rigidifix ${ }^{\circledR}$ Relato preliminar. Acta ortop. 2004;12(4):212-216.

12. Ataides $G$, Oliveira M, Junior PL, Araujo R, Henrique P, Lima R. et al. Resultados clínicos e funcionais da cirurgia de reconstrução do LCA contralateral em médio prazo. Universitas: Ciências da Saúde 2013;11(1):19-28.
13. Bottoni CR, Liddell TR, Trainor TJ, Freccero DM, Lindell KK. Postoperative range of motion following anterior cruciate ligament reconstruction using autograft hamstrings: a prospective, randomized clinical trial of early versus delayed reconstructions. Am J Sports Med. 2008;36(4):656-662.

14. Kisner C, Colby LA. Exercícios Terapêuticos. 4 ed. São Paulo: Manole; 2005.

15. Bonfim TR, Paccola CAJ. Propriocepção após reconstrução do ligamento cruzado anterior usando ligamento patelar homólogo e autólogo. Rev Bras Ortop 2000;35(6):194-201.

16. Terreri ASAP, Greve JMD, Amatuzzi MM. Avaliação Isocinética do Joelho do Atleta. Rev Bras Med Esporte 2001;7(5):170-174.

17. Kase K, Wallis J, Kase T. Clinical therapeutic applications of the kinesio taping method. 2 ed. Kenl Kai Co. TOKYO: Japan; 2003.

18. Oliveira VMA, Batista LSP, Pitangui ACR, Araújo RC. Efeito do Kinesio Taping na dor e discinesia escapular em atletas com síndrome do impacto do ombro. Revista Dor 2013;14(1):27-30.

19. Williams S, Whatman C, Hume PA, Sheerin K. Kinesio taping in treatment and prevention of sports injuries: a meta-analysis of the evidence for its effectiveness. Sports Med 2012;42(2):153-164.

20. Yasukawa A, Patel P, Sisung C. Pi-lot Study: Investigating the Effects of Kinesio Taping ${ }^{\circledR}$ in an Acute Pediatric Rehabilitation Setting. The American Journal of Occupational Therapy 2006;60(1):104-110.

21. Georgoulis AD, Ristanis S, Moraiti CO, Paschos N, Zampeli F, Xergia S. et al. $A C L$ injury and reconstruction: clinical related in vivo biomechanics. Orthop Traumatol Surg Res 2010;96(8):119-128.

22. Hernandez AJ. Instabilidade Anterior. In: Camanho, G. L. Org. Patologia do joelho. São Paulo: Sarvier; 1996.

23. Chatrenet $Y$, Kerkour K. Fisioterapia das lesões ligamentares do joelho no atleta. Barueri, São Paulo: Manole; 2002.

24. Veiga PHA, Albuquerque RFM, Teodoro WPR, Martins JVG, Alves RLBR. Correlação entre a análise histológica e avaliação funcional do joelho de paciente submetidos à reconstrução do ligamento cruzado anterior. Rev Bras Fisioter 2007;11(4):253-260.

25. Marins P, Oliveira R, Lopes AM. Estudo das alterações do perímetro do membro inferior, da amplitude de movimento e da dor no joelho, após aplicação da banda neuromuscular, em indivíduos submetidos à artroplastia total do joelho, no período pós-operatório imediato. APBNM, Notícias de Banda Neuromusculares [26 out 2010]. 2009. Disponível em: http://www.aneid.com.br/pdf/news_bandas_nov2009_Brasil.pdf.

26. Calero SPA, Martinez GAC. Efectos del vendaje neuromuscular: una revisión bibliográfica. Revista ciência salud 2011;10(2):273-274. 